Renate Kirmse

Praxishandbuch Kompetenztraining 



\section{Renate Kirmse}

\section{Praxishandbuch}

Kompetenztraining

Projektarbeit in Schul- und Öffentlichen Bibliotheken 
ISBN 978-3-11-067667-9

e-ISBN (PDF) 978-3-11-067676-1

e-ISBN (EPUB) 978-3-11-067680-8

Library of Congress Control Number: 2021932959

Bibliografische Information der Deutschen Nationalbibliothek

Die Deutsche Nationalbibliothek verzeichnet diese Publikation in der Deutschen Nationalbibliografie; detaillierte bibliografische Daten sind im Internet über http://dnb.dnb.de abrufbar.

(C) 2021 Walter de Gruyter GmbH, Berlin/Boston Coverabbildung: ArtistGNDphotography/E+/Getty Images

Satz: Integra Software Services Pvt. Ltd.

Druck und Bindung: $\mathrm{CPI}$ books GmbH, Leck

www.degruyter.com 